\title{
Phytoprotection
}

\section{A note on the detection of the carrot weevil in Nova Scotia}

phytoprotection

\section{J.-P.R. LeBlanc et G. Boivin}

Volume 74, numéro 2, 1993

URI : https://id.erudit.org/iderudit/706041ar

DOI : https://doi.org/10.7202/706041ar

Aller au sommaire du numéro

Éditeur(s)

Société de protection des plantes du Québec (SPPQ)l

ISSN

0031-9511 (imprimé)

1710-1603 (numérique)

Découvrir la revue

Citer cet article

LeBlanc, J.-P. \& Boivin, G. (1993). A note on the detection of the carrot weevil in Nova Scotia. Phytoprotection, 74(2), 113-115. https://doi.org/10.7202/706041ar

\section{Résumé de l'article}

Le charançon de la carotte, Listronotus oregonensis [Coleoptera:

Curculionidae], est un ravageur important des cultures de légumes dans le nord-est de l'Amérique du Nord. Cette espèce n'avait cependant jamais été détectée auparavant dans les Maritimes ou à Terre-Neuve. En 1985, 1986 et 1988, des tentatives de détection de ce ravageur en Nouvelle-Ecosse ont été infructueuses. En 1992, des pièges thigmotactiques faits de plaquettes de bois et appâtés avec des carottes fraîches, ont été utilisés dans trois champs de carottes (Daucus carota), et six spécimens ont été capturés durant la migration printanière de l'insecte entre ses sites d'hivernation et un champ de carottes situé près de Great Village, en Nouvelle-Ecosse. 


\title{
A note on the detection of the carrot weevil in Nova Scotia
}

\author{
Jean-Pierre R. Le Blanc ${ }^{1}$ and Guy Boivin ${ }^{2}$
}

Received 1993-02-15; accepted 1993-08-20

The carrot weevil, Listronotus oregonensis [Coleoptera: Curculionidae], is a significant pest of vegetable crops in northeastern North America. However, the species had not been previously detected in Atlantic Canada. In 1985, 1986, and 1988, attempts to detect this pest in Nova Scotia were unsuccessful. In 1992 , in one of three carrot (Daucus carota) fields monitored using thigmotactic wooden-plate traps baited with fresh carrots, six individuals were captured during the spring migration of the insect from overwintering sites into a carrot field near Great Village, Nova Scotia.

\section{Le Blanc, J.-P.R. et G. Boivin. 1993. Une note sur la présence du charançon de la carotte en Nouvelle-Écosse. PHYTOPROTECTION 74: 113-115.}

Le charançon de la carotte, Listronotus oregonensis [Coleoptera: Curculionidae], est un ravageur important des cultures de légumes dans le nord-est de l'Amérique du Nord. Cette espèce n'avait cependant jamais été détectée auparavant dans les Maritimes ou à Terre-Neuve. En 1985, 1986 et 1988, des tentatives de détection de ce ravageur en Nouvelle-Écosse ont été infructueuses. En 1992, des pièges thigmotactiques faits de plaquettes de bois et appâtés avec des carottes fraîches, ont été utilisés dans trois champs de carottes (Daucus carota), et six spécimens ont été capturés durant la migration printanière de l'insecte entre ses sites d'hivernation et un champ de carottes situé près de Great Village, en Nouvelle-Écosse.

The carrot weevil, Listronotus oregonensis (Le Conte) [Coleoptera: Curculionidae], is an important pest of vegetable crops in the northeast regions of the United States (Simonet and Davenport 1981). In Canada, it attacks parsley (Pastinaca sativa L.) and celery (Apium graveolens L. var. dulce), but it is economically important only on carrots, (Daucus carota L.), particularly in Ontario and Québec (Boivin 1985; Perron 1971; Stevenson 1976). Literature and regional collection sear-

1. A.D. Pickett Entomological Museum and Research Laboratory, Department of Biology, Nova Scotia Agricultural College, P.O. Box 550, Truro, Nova Scotia, Canada B2N 5E3

2. Agriculture Canada, Research Station, 430 Gouin Blvd., Saint-Jean-sur-Richelieu, Québec, Canada J3B 3E6 ches in 1984 and 1985 indicated that this pest was not present in Atlantic Canada. Because carrot acreage in Nova Scotia was and still is increasing rapidly, efforts to detect this pest in Atlantic Canada became important. We report here the first mention of $L$. oregonensis in Nova Scotia. Because of their ease of use and potential to detect carrot weevils, thigmotactic wooden plate traps baited with fresh carrots were used (Boivin 1985).

During the late spring of 1985 and 1986, an ca. 12.0 ha carrot field (cv. Red Cored Chantenay) located near Belmont, Nova Scotia $\left(45^{\circ} 26^{\prime} \mathrm{N} 63^{\circ} 23^{\prime} \mathrm{W}\right)$ was selected. This field was adjacent to a field of similar size that had been in carrot production (cv. Red Cored Chantenay) for the previous $2 \mathrm{yr}$. At the end of the field, 18 traps were installed where nearby overwintering sites of weeds and leaf litter favour- 
able for carrot weevils had been identified. The traps were monitored twice weekly during the migration period of the insect, from early May to late June. In 1988, a similar experiment was also carried out in two fields (cv. Scarlet Nantes Touchon) of ca. 6.0 ha each, one located near Waterville, and the other within a $5 \mathrm{~km}$ distance near Berwick, Nova

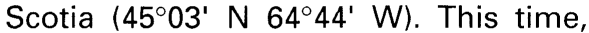
however, only nine traps were installed in each field and the traps were monitored once a week during the migration period of the insect. Lastly, in 1992, three other fields ( $c a .6 .0$ ha, 8.5 ha, and 9.0 ha) were selected near Great Village, Nova Scotia $\left(45^{\circ} 25^{\prime} N 63^{\circ} 36^{\prime} W\right)$. In this area of the province, there was a large increase in carrot production in recent years. The 6.0 ha field was adjacent to the 9.0 ha one. The 9.0 ha field had been in carrot production in 1991. The 8.5 ha field, located within $0.5 \mathrm{~km}$ of the other two, was adjacent to another field where carrot had been produced the year before. For all these Great Village fields, the cultivar used was Red Cored Chantenay. In 1992, all the Great Village fields were treated with insecticides according to regional agricultural practices (Anonymous 1992).

In each of these fields, six woodenplate traps were set, three at each end of each field, again near possible overwintering sites. These traps were monitored during the period from the first week of May to the end of July. This was carried out on a weekly basis until the first capture and thereafter on a bi-weekly pattern until late June. The weekly visits then resumed until trapping was terminated.

Captured beetles were examined and those resembling carrot weevils were sent to Dr. R.S. Anderson, Coleopterist at the Canadian Museum of Nature (C.M.N.), in Ottawa for further verification and official determination.

In the carrot field in which captures occurred, carrot weevil damage assessment was carried out before (21 September 1992) and after harvest (25 October 1992). The post-harvest assessment was possible because mechanical harvesters do not collect all the carrots. For these two assessments, 50 and 30 carrots, respectively, were randomly collected at each end of the field.
Six of the captured beetles were positively identified as the carrot weevil, $L$. oregonensis, and all came from four of the six traps located in the 8.5 ha field. This field was adjacent to a field to the north which was in carrot production the year before, and which was separated from it by a $10 \mathrm{~m}$ wide edge of bushes and trees. Three beetles were captured from each of the east and west ends of the field. Carrots in the 8.5 ha field were sown on 16 May 1992. The first captures occurred on 27 May. At that time, carrots were just starting to emerge, and 85 degree-days (DD) had accumulated over the base air temperature of $7^{\circ} \mathrm{C}$ common to the development of the pest and the crop (Lorenz and Maynard 1988; Simonet and Davenport 1981). This is consistent with the finding that feeding punctures on bait carrots placed on the ground would first appear around $100 \mathrm{DD}_{7 \circ \mathrm{C}}$ (Boivin 1988). Therefore, weevils in Nova Scotia would be active in fields prior to the cotyledon stage (8 June 1992) which would be about $200 \mathrm{DD}_{7 \mathrm{C}}$ for carrots sown about mid-May, as in that field. On average, the first captures would be about one month later than those observed in Québec (Boivin 1985). Although monitoring lasted until the end of July, the last weevils were caught on 21 June 1992 at around $250 \mathrm{DD}_{7^{\circ} \mathrm{C}}$. Phenologically, this time coincides with the second true leaf stage for carrots sown in mid-May, and captures tend to dramatically decline at about the second true leaf stage (Boivin 1985). At the end of June, the captures met the economic threshold established for that pest in Quebec and Ontario, i.e. the cumulative captures of one carrot weevil per trap (Boivin and Brodeur 1992).

In the pre-harvest damage assessment, carrots sampled at the east end of the field were not damaged by the carrot weevil. At the west end of the field, one carrot was damaged with the distinctive tunnelling of the developing grub being readily observed in the upper third of the main root (Stevenson 1981). In the postharvest damage assessment, again only one carrot with weevil damage was detected, but it was amongst those sampled at the east end of the field. The overall damage was about $1.4 \%$, or well below the acceptable level of $5.0 \%$ damage. This may be the result of the two 
insecticide applications directed at other carrot insect pests, even if the economic threshold had been met. One treatment, applied in late June, consisted of diazinon [O-O-diethyl-O-(2-isopropyl-6-methyl -5 -pyrimidinyl)phosphorothioate] at the recommended rate of $0.55 \mathrm{~L}$ a.i. ha ${ }^{-1}$ and was directed against the first generation of the carrot rust fly, Psila rosae (F.) [Diptera: Psilidae]. The other one, applied in early July, was cypermethrin [( \pm )alphacyano-(3-phenoxyphenyl)methyl $(+)$ cis,trans-3-(2,2-dichloroethenyl) -2,2-dimethyl-cyclopropane carboxylate] at 70 $\mathrm{mL}$ a.i. ha ${ }^{-1}$ against cutworms, Euxoa messoria(Harr.) [Lepidoptera: Noctuidae] and E. ochrogaster (Gn.) [Lepidoptera: Noctuidae]. In Québec, treatments against the carrot rust fly will not control the weevil effectively because these treatments are directed at the rust fly second generation. In Nova Scotia, occasionally a treatment is directed at the first generation of rust flies. Thus in this case, these two insecticide applications would have represented a valid chemical control for the carrot weevil in terms of timing. Neither of the two insecticides used were, however, recommended ones for carrot weevil control. In either Québec or Ontario, the recommended insecticide is phosmet [ $\mathrm{N}$-(mercaptomethyl) phthalimide S-(O,O-dimethyl phosphorodithioate)] at $1.125 \mathrm{~kg} \mathrm{ha}^{-1}$ (50 WP).

Carrot producers should be informed of the possible occurrence of this pest in their fields now that it has been detected in Nova Scotia, and a more comprehensive detection effort should be implemented by extension personnel wherever significant carrot production occurs in the Maritime Provinces. Also, work on the seasonal history of this weevil in the region should be initiated to adjust recommendations made to producers on a regional basis. This is especially true if treatments against the first generation of carrot rust flies become generalized in Atlantic Canada.

\section{ACKNOWLEDGEMENTS}

The authors thank Dr. R.S. Anderson (C.M.N.) for taxonomical assistance, Ms. D. Thibodeau (Agric. Canada) for laboratory work, Ms. A.D. Butler (N.S.A.C.) for field work, and $\mathrm{Mr}$. Lorne $\mathrm{M}$. Crozier (N.S.D.A.M.) for the 1988 monitoring.

\section{REFERENCES}

Anonymous. 1992. Atlantic Provinces vegetable crops guide to cultivar selection and chemical pest control. Pub. no. 1400A. Agdex no. 250.51 pp.

Boivin, G. 1985. Evaluation of monitoring techniques for the carrot weevil, Listronotus oregonensis [Coleoptera: Curculionidae]. Can. Entomol. 117: 927-933.

Boivin, G. 1988. Effects of carrot developmental stages on feeding and oviposition of carrot weevil, Listronotus oregonensis (Le Conte) [Coleoptera: Curculionidae]. Environ. Entomol. 17: 330-336.

Boivin, G., and L. Brodeur. 1992. Dépistage systématique des ravageurs: impact sur les pratiques phytosanitaires en cultures maraîchères au Québec. Bull. Tech. Agric. Canada Stn. Res. St-Jean-sur-Richelieu A54-9/27F. 16 pp.

Lorenz, O.A., and D.M. Maynard. 1988. Vegetable growers, 3rd ed. Wiley, New York. 456 pp.

Perron, J.P. 1971. Insect pests of carrots in organic soil of southwestern Quebec with special reference to the carrot weevil, Listronotus oregonensis [Coleoptera: Curculionidae]. Can. Entomol. 103: 14411448.

Simonet, D.E., and B.L. Davenport. 1981. Temperature requirements for development and oviposition of the carrot weevil. Ann. Entomol. Soc. Am. 74: 312-315.

Stevenson, A.B. 1976. Seasonal history of the carrot weevil, Listronotus oregonensis [Coleoptera: Curculionidae], in the Holland Marsh, Ontario. Proc. Entomol. Soc. Ont. 107: 71-78.

Stevenson, A.B. 1981. Carrot insects. Min. Agric. Food Ont. Factsheet 81-007, Agdex 258/605. 4 pp. 